\title{
Intonation of Russian Declarative Sentence: Methodology for Teaching Foreign Students
}

\section{Entonación de la oración declarativa rusa: metodología para enseñar a estudiantes extranjeros}

\author{
Marina Nikolaevna Shutova \\ A.S. Pushkin State Russian Language Institute, Moscow, Russia. \\ ORCID: https://orcid.org/0000-0002-5530-9449 \\ Tatyana Vyacheslavovna Nesterova \\ A.S. Pushkin State Russian Language Institute, Moscow, Russia. \\ ORCID: https://orcid.org/0000-0002-1799-1897

\section{Elena Olegovna Naumova*} \\ Moscow Polytechnic University, Moscow, Russia. \\ ORCID: https://orcid.org/0000-0003-1257-686X
}

Received 02-12-20 Revised 03-13-20 Accepted 07-13-20 On line 08-29-20

*Correspondence

Email: naumova.e.o@bk.ru

\section{Cite as:}

Shutova, M.N., Nesterova, T.V., \& Naumova, E.O. (2020) Intonation of Russian Declarative Sentence: Methodology

for Teaching Foreign Students. Propósitos y Representaciones, 8 (SPE2), e682. Doi: http://dx.doi.org/10.20511/pyr2020.v8nSPE2.682 


\section{Summary}

The article deals with teaching Russian intonation of declarative sentences to foreign students. The emphasis is placed on the way teaching materials are presented. In particular, the variable rows for intonation patterns in declarative sentences have been developed, as well as the teaching of syntagmatic segmentation and intonation patterns in complex utterances. This method of working with foreigners is efficient for teaching foreign students the Russian declarative intonation which manifests in verbal communication and reading.

Keywords: Declarative Sentence; Russian Intonation; Teaching Foreign Students.

\section{Resumen}

El artículo trata sobre la enseñanza de la entonación rusa de oraciones declarativas a estudiantes extranjeros. Se pone énfasis en la forma en que se presentan los materiales didácticos. En particular, se han desarrollado las filas variables para patrones de entonación en oraciones declarativas, así como la enseñanza de la segmentación sintagmática y los patrones de entonación en expresiones complejas. Este método de trabajar con extranjeros es eficaz para enseñar a los estudiantes extranjeros la entonación declarativa rusa que se manifiesta en la comunicación verbal y la lectura.

Palabras clave: Oración declarativa; Entonación Rusa; Enseñando a estudiantes extranjeros.

\section{Introduction}

The main goal of a foreign student in the study of the Russian language is to master the ways of expressing their intentions in Russian in monologic and dialogic speech. For successful dialogic communication, the student must:

- "control the communication, be the proactive side (enter, maintain and end the conversation according to the progress of the situation) while achieving the planned understanding with native speakers of the Russian language;

- exchange information with an interlocutor;

- express various emotions and emphasize the importance of facts, events and impressions;

- considering the nature of the situation, choose the form of expressing an opinion and clearly state their point of view;

- explain their point of view, providing the necessary reasoning and comments while maintaining the appropriate emotional state of communication; reach an agreement when discussing practical tasks;

- discuss plans, assumptions, hypotheses, highlighting the logic of causal relationships.

- In the monologue:

- describe in sufficient detail their own experience, the subjectively important events;

- relay to the interlocutor in brief the contents of what the speaker read or heard;

- $\quad$ state the position on a certain subjectively important problem, explaining the advantages and disadvantages of different solutions;

- $\quad$ provide arguments for and against a point of view, logically linking their thoughts;

- make assumptions regarding the possible development of events" (Trebovaniya po russkomu yazyku kak inostrannomu, 2004).

\section{Literature review}

Communicative aims and intentions are always present in the speaker's mind but they are explicitly expressed through language means. Within the speech actions that are the basic units 
of communication, the semantic and psychological components (communicative intentions) remain permanent. According to V.A. Artemov, the number of speech actions is incalculable, but it can be narrowed down to four classes (communicative types): declarative, interrogative, imperative and exclamatory (Artemov, 1969).

Foreign students should be able to not only respond to the interlocutor's remarks, answer questions and correctly pose them, but also to independently describe a subject, talk about an event, express their opinion, etc. These skills are connected to the formation of another psycholinguistic plane - the development of monologic speech. According to A.A. Leontev, "monologic speech should be intentionally taught whereas dialogic speech requires training based on some 'speech stereotypes'" (Leontev, 1970: 17).

Monologic speech in its oral form is one person's speech-message, speech-information wherein "the topic of the message does not come from the interlocutor's stimuli or the communication situation, rather from the inner idea of the person formulating the message, from their thoughts and the content that they want to convey in an expanded statement" (Mets, 1973: 267). The types of monologic speech vary depending on the social function of the language that enables the monologue. V.V. Vinogradov distinguishes between three important social functions of language - communication, information and influence (Vinogradov, 1963). The functions are interconnected and realized through different styles and, therefore, different types of monologic speech: the extra-occupational colloquial style by the communicative function; the formal, official-documentary, and scientific styles by the information function; the journalistic style and the style of fiction by the influence function.

Intonation plays an important part in expressing intentions in different types of monologic utterances. Intonation is one of the key means for the realization of communicative acts, it transforms sentences into utterances. Intonation distinguishes between stylistic particularities of speech and is characteristic of orthoepically correct speech in a given language (Khromov, Sokolova, 2014).

\section{Methods}

Speech intonation contains a lot of communicative, syntactic, logical and modal information. Moreover, it informs one about the interlocutor: whether they speak the correct literary language, what their speech characteristics are, their type of higher nervous function and personal characteristics (Artemov, 1969; Khromov, 2000). This unity of syntax, vocabulary, intonation and the meaning of the utterance is represented the most clearly in the variable rows created by E.A. Bryzgunova $(1986,1989)$. According to the author, the variable rows of utterances contain the foundations of Russian speech. The utterances express questions, statements, negations, volitions (demand, request, advice, permission, etc.), addresses and some others.

This article deals with the intonation of declarative sentences. A declarative sentence is "a sentence containing positive information directed from the speaker (writer) to the person perceiving the intonation as opposed to an interrogative sentence which is primarily aimed at obtaining information" (Filin, 1979: 212). All objectively-modal meanings can be expressed in a declarative sentence: both real (realized in present, past and future), as well as unreal (the possible, the desired, the necessary, the required). Declarative sentences have their structural and intonational patterns. Let us take a closer look at them.

Variable rows of sentences expressing messages and the reactions to them:

1) statement, message about something, information: 
Zavtra u vas ekzamen [Tomorrow you have an exam] (Intonation pattern (IP)-1,2).

Zavtra / u vas ekzamen [Tomorrow / you have an exam] (IP-3,4,6 /1).

Replying remarks:

a) confirming the interlocutor's ideas, joining the interlocutor's ideas, expressing an identical idea, continuing an idea: And me too]

- Da, pravilno. - Ya tozhe tak dumayu. - I ya tozhe ... [Yes, correct. - I think so too. -

б) disagreement, objection, expressing an opposite idea:

- Net. - A ya net. - A ya dumayu, chto ... [ No. - And I don't. - And I think that...]

2) expanded sentences with lists of information with unattached phrases and subordinate clauses with generalizing words:

$V$ nashem institute uchatsya studenty iz raznykh stran: Yaponii, Kitaya, Vetnama, Kuby, Italii i drugikh stran [There are students from different countries studying at our institute: Japan, China, Vietnam, Cuba, Italy and other countries].

There is a possibility to use different IPs $(1,2,3,4,6)$ and types of syntagmatic segmentation.

3) sentences with comparison:

- Eto slovar, / a eto uchebnik. [This is a dictionary / and this is a textbook] - Eto / slovar, / a eto/ uchebnik. [This / is a dictionary / and this / is a textbook]

4) sentences with contrasting information:

- On ne student, / a shkolnik. [He is not a student / but a schoolboy] - On shkolnik, / a ne student [He is a schoolboy / and not a student].

5) sentences with explanation:

- Cherez nedelyu / my uezzhaem, - skazal starosta gruppy.

- Nina Ivanovna Tumanova, dekan fakultetal - v otpuske.

(Direct speech, parenthetical phrases).

6) sentences expressing an assessment:

- On ochen umnyi $[\mathrm{He}$ is very smart] $(I P-1,2)$. - On takoi umnyi [He is so smart] (IP$2,5,6) !-$ Umnyi on [He thinks he is so smart] $(I P-2,6) !-$ Kakoi on umnyi [How smart he is!] (IP$5,6)$ !

7) sentences expressing a promise of information without revealing it:

- A chto ya znayu! - A kto k nam priekhal! [I know something! - Look who has arrived!] (IP-6).

8) sentences expressing obligation, need: 
- Mogla by pozvonit! - Dolzhen soobrazhat! (uzhe vzroslyi) [You could have called! You should understand! (old enough already)] (IP-2, 4).

9) sentences expressing joy, satisfaction:

- A my v kino byli! - A ya pyaterku poluchila! [And we have been to the cinema! - And I have got an A!] (IP-6).

The replying remarks for points 6, 8, 9 are the same as in point 1 (Shutova, 2005: 211-

The work on intonation patterns of speech is closely connected to the skill of expressive reading which contributes to the automation of rhythmic and intonational patterning of utterances in different types of speech (Ageeva et al. 1989). For correct and expressive reading, foreign students should develop the skill of syntagmatic segmentation of the utterance and the text, intonation patterning of final and non-final syntagmas in socio-journalistic, scientific and literary texts first by listening to an example and following it, then by independently interpreting intonation patterns of utterances.

Sentence segmentation is connected to the notion of syntagma which is defined and explained in the works by L.V. Shcherba (Shcherba, 1957). The scholar understood the term "syntagma" as a group of words (or a word) that form a semantic unity for the given context or situation that occurs in the process of speech-thought and follows a phonetic pattern. The composition and structure of the syntagma depend on the way words collocate in a language, their relationships and functions in a sentence, the structure of the sentence and its members. The sentence can either be a single syntagma (monosyntagmatic sentence) or several (polysyntagmatic). When speaking of polysyntagmatic sentences, E.A. Bryzgunova introduces the notion of minimal syntagmas which means they cannot be divided any further considering the syntactical relations between words (Bryzgunova, 1963; Shutova, 2017).

In a simple sentence, it is:

- $\quad$ the subject phrase with a simple or compound predicate (Beloe zdanie/ - eto poliklinika [The while building / is a medical clinic]. Devushka s kosoi/ stoyala u otkrytogo okna [The girl with the braid/ was standing by the open window].);

- $\quad$ subject phrases (V seredine iyunya / detei otpravili na dachu [In the middle of June / the children were sent to the country]. Nedaleko ot ozeral prokhodila glavnaya doroga na Moskvu [Not far from the lake / there was the main road to Moscow]. Iz-za bolezni artista/ spektakl prishlos otmenit [Due to the artist's illness / the performance had to be canceled].);

- $\quad$ object phrase at the beginning of the sentence (Takoe otnoshenie k kollegam/ ya ne privetstvuyu [Such attitude towards colleagues / is not welcome by me].);

- groups of words that the objects refer to before objects with the words: krome, za isklyucheniem, vmesto, pomimo etc. (Za isklyucheniem ottsa / vse poekhali na more. Krome trekh zhurnalov / prishlos vzyat eshche dve knigi. [Except my father / everyone went to the sea. In addition to three magazines / I had to take two more books]);

- $\quad$ participle phrase before a personal pronoun (Ubezhavshie ot grozy, / oni veselo zanimali mesta $v$ avtobuse [Having escaped the thunderstorm, / they had fun taking their places on the bus]);

- adverbial participle phrase before the main clause (Sverkaya na solntse, / reka stremitelno sbegala s gor [Sparkling in the sun, / the river swiftly ran down the mountains]); 


\section{in complex sentences:}

- in compound sentences:

with the conjunction "i"[and] meaning sequence and the result of action (Podul veter, $/ i$ listok otorvalsya ot vetki [The wind blew, / and the leaf came off the branch]);

when comparing and contrasting (My edem v Moskvu, / a on v Peterburg. Slon bolshoi, / no ne zloi [We are going to Moscow / and he is going to Petersburg. The elephant is big / but not bad-tempered]);

- in complex sentences:

beginning with subordinate clauses containing conjunctions and connective words (Kogda my seli v poezd, / bylo pochti vosem chasov. Chtoby byt zdorovym, / nado zanimatsya sportom [When we got on the train, / it was almost eight o'clock. To be healthy, / one needs to do sports]);

with correlative members in the main and subordinate clauses (Sdelai eto tak, / chtoby vse byli dovolny. Ya sdelayu vse tak, / kak vy khotite. [Do it / so that everyone is satisfied. I will do everything / the way you want]);

in complex asyndetic sentences with the meaning of condition and time (Zhizn prozhit / - ne pole pereiti. Sdelal delo / - gulyai smelo [Living life / is not like crossing a meadow. When the business is done / go have your fun]).

Already at the initial stage, the students should learn to divide sentences into syntagmas and be able to apply appropriate intonation patterns, i.e. to master syntagmatic segmentation of utterances. Without the knowledge of the syntactical structure of language, students divide utterances artificially and group the words that are not syntactically connected. That is why students must become acquainted with the most common syntactical structures that form syntagmas.

\section{Noun phrase:}

- adjective + noun

khoroshii drug, russkii yazyk, interesnyi chelovek [good friend, Russian language, interesting person]

- pronoun (possessive and demonstrative) + noun

moi prepodavatel, tvoi drug, ee babushka, etot dom [my teacher, your friend, her grandmother, this house]

- ordinal numeral + noun

pervyi urok, tridtsataya stranitsa, vtoroi etazh [first lesson, thirtieth page, second floor]

- quantitative noun + noun

tri studenta, pyat tetradei, shest chasov, dvadtsat let [three students, five notebooks, six hours, twenty years]

- participle + noun

poyushchaya devushka, znayushchii chelovek, krichashchii rebenok [singing girl, knowledgeable man, screaming child]

- noun + noun in the genitive case 
tsentr goroda, uchastnik konferentsii, vecher poezii [city center, conference participant, poetry night]

- preposition + noun phrase

$v$ pyat chasov, na vtorom kurse, s podrugoi, $v$ zhurnale poseshchaemosti [at five o'clock, in the second year, with a friend, in the gradebook].

\section{Verb phrase:}

- personal pronoun + verb are friends]

on izuchaet, slushayu ya, ona tantsuet, druzhat oni [he studies, I listen, she dances, they

- compound verb form

ona budet zanimatsya, ya budu zhdat, oni budut otdykhat [she will be busy, I will be waiting, they will be resting]

- conjugated verb forms + infinitive

reshili priglasit, khochu napisat, ne mogli poiti [decided to invite, I want to write, could not go]

- verb + adverb

idti bystro, govorit pravilno, pisat nekrasivo [go fast, speak correctly, write sloppily]

- verb + direct object

slushat lektsiyu, chitat knigu, pisat referat [listen to a lecture, read a book, write a report]

- verb + dependent nouns

vstretitsya s podrugoi, interesovatsya kino, pisat ruchkoi [meet a friend, be interested in a movie, write with a pen] (Shutova, 2005, pp. 216-217).

At the advanced stage of studying Russian as a foreign language, students already have a certain speech level, and the material on intonation should be provided with an appropriate generalization. Thus, intonation patterns of syntagmas in declarative sentences can be summarized in a table (Table 1). Then an example can be used to explain how the table works.

Table1.

Intonation of declarative sentences

\begin{tabular}{lll}
\hline Final syntagma & Finished syntagma & IP-1 \\
\hline & Finished syntagma & IP-1,2,3,4,6 \\
\cline { 2 - 3 } Non-final syntagma & Unfinished syntagma & IP-3,4,6 \\
\hline
\end{tabular}

Example: U russkogo derevyannogo zodchestva / est svoi traditsii, / svoya istoriyall [Russian wooden architecture / has its own traditions, / its own history //].

The first syntagma "u russkogo derevyannogo zodchestva" is non-final unfinished, IP$3,4,6$ are used.

The syntagma "est svoi traditsii" is non-final, finished, IP-1,2,3,4,6 are used.

The syntagma "svoya istoriya" is final, finished, IP-1 is used. 
This table of intonation patterns for syntagmas and sentences can also be used in verse. However, it should be noted that IP-4 is not used in poetry as this pattern is typical of formal communication.

The skills of syntagmatic division and intonation pattern usage in syntagmas will also be useful during oral monologic utterances in public speaking, expressing one's point of view, telling a story.

The main way of improving intonation at the advanced stage of studying (level B1-B2) is the method of communicative analysis of the spoken sentence and text as "the meaning of the spoken sentence (utterance) is the result of the interaction of meanings expressed by the syntactical structure, the vocabulary, the intonation as well as the semantic interaction of the sentence with one of the preceding or following sentences" (Bryzgunova, 1979: 58). The communicative text analysis is based on the following principles: 1) the main unit of practice is a sentence (an utterance); 2) the analyzed utterance is commented on from the point of all of its components: the syntactical structure, intonation, semantic connections to the context; 3) the utterance is considered dynamically while taking into account the possible context-based lexicalgrammatical and intonation transformations and the corresponding semantic and emotionalstylistic shades of meaning; 4) the final goal of working on the utterance is to actively master it including the lexical-grammatical and intonational aspects. Such an analysis of utterances turns the work on intonation into work on speech development which is the final goal for foreigners studying the Russian language (Mukhanov, 1989).

The declarative, interrogative and imperative sentences described in syntax show their communicative potential in different ways in everyday communication, especially when realizing the pragmalinguistic category of indirectness (Nesterova, 2012, 2015, 2016). Thus, the aforementioned declarative sentences actively take part in forming contextual-situational indirect speech acts ("the second degree of indirectness") (CSISA) (Nesterova, 2012, 2015) that have not been systematically reviewed in existing grammars or textbooks. However, they amount to a substantial share of one's everyday communications as up to $70 \%$ of meaning is conveyed indirectly, for example, Chto-to duet [There seems to be a draught]. (IP-2) - an indirect request to close the window; U menya zavtra ekzamen [I have an exam tomorrow]. (IP-2) - an indirect refusal; Uzhe odevayus [Already getting dressed]. (IP-1) - indirect consent to the request (to go to the shop), Telefon molchit [The phone is silent]. (IP-1) - an indirect request (and simultaneously a prohibition) not to use the mobile phone in public places; Po-moemu, uzhe vsya marshrutka znaet o Vashikh planakh [The whole bus seems to know about your plans already]. (IP-2) - a reproach, an indirect request to speak quieter on the mobile phone (simultaneously a prohibition), Obed gotov [The lunch is ready]. (IP-2) - an indirect invitation to the table, $U$ menya roditeli na dachu uekhali, kvartira svobodna [My parents have gone to the country, the flat is empty]. (IP-2) - an indirect suggestion (and simultaneously an invitation) etc. A lot of these CSISA are polyintentional and constitute hints (Nesterova, 2012, 2015). Intonation and non-verbal elements of communication play the key part in decoding the intentions of these speech acts.

\section{Conclusion}

The intonation of the spoken text is not random or accidental, entirely dependent on extralinguistic conditions and the speaker's personal traits. Instead, it is determined by several linguistic factors: the vocabulary of the text, its grammar, especially its syntax, the word order and the actual division, the stylistics and expressive coloring, modality and other semantic categories present in the text.

Native speakers use intonation intuitively, they do not think about how to express joy or anger, dissatisfaction, insistence or request. It is very difficult for foreigners to identify jokes, irony, disappointment, distrust, doubt, etc. in the Russian language (Shutova, et al., 2019). We offer a teaching aid that will help foreign students to learn to understand the meaning expressed 
in the texts of monologues and dialogues and teach them to read and speak correctly in different life situations (Shutova, 2015).

Another promising direction of research is the comparative description of languages and cultures based on the CSISA used in them which will allow identifying universal, as well as culturally specific, manifestation of the pragmalinguistic category of indirectness in different communicative situations (if all the speech intentions are realized) (Saveleva, 1991). The results of such a study can be useful in the theory and practice of teaching Russian as a second language.

\section{References}

Ageeva, T.N., Zubova, Zh.A., Koreneva, L.A. (1989). Mesto i rol vyrazitelnogo chteniya v sisteme zanyatii po fonetike so studentami-filologami vklyuchennoi formy obucheniya [The place and role of expressive reading in the system of phonetics classes with exchange students of linguistics]. Fonetika: teoriya i praktika prepodavaniya. Materialy I mezhdunarodnogo simpoziuma MAPRYaL. Moscow: UDN.

Artemov, V.A. (1969). Psikhologiya obucheniya inostrannym yazykam [Psychology of teaching foreign languages]. Moscow: Prosveshchenie.

Bryzgunova, E.A. (1963). Prakticheskaya fonetika i intonatsiya russkogo yazyka [Practical phonetics and intonation of the Russian language]. Moscow: Izd-vo MGU.

Bryzgunova, E.A. (1979). Smyslovoe vzaimodeistvie predlozhenii [Semantic interaction of sentences]. In the collection Sintaksis teksta. Moscow.

Bryzgunova, E.A. (1986). Vvodnyi fonetiko-razgovornyi kurs russkogo yazyka (dlya nefilologov) [Introductory course of phonetics and conversation in the Russian language (for non-linguists)]. Moscow: Russkii yazyk.

Bryzgunova, E.A. (1989). Obem dialogicheskoi rechi na nachalnom etape obucheniya russkomu yazyku kak inostrannomu [Volume of dialogic speaking at the beginning of teaching Russian as a foreign language]. Fonetika: teoriya i praktika prepodavaniya. Materialy I mezhdunarodnogo simpoziuma MAPRYaL. Moscow: UDN.

Vinogradov, V.V. (1963). Stilistika, teoriya poeticheskoi rechi, poetika [Stylistics, theory of poetic speech, poetics]. Moscow: Nauka, AN SSSR.

Leontev, A.A. (1970). Nekotorye problemy obucheniya russkomu yazyku kak inostrannomu (psikholingvisticheskie ocherki) [Challenges of teaching Russian as a foreign language (psycholinguistic essays)]. Moscow: Izd-vo Moskovskogo universiteta.

Mets, N.A. (1973). K probleme razvitiya navykov monologicheskogo vyskazyvaniya [On mastering monologic skills]. Poiski optimalnykh putei upravleniya uchebnym protsessom. Moscow: Vysshaya shkola.

Mukhanov, I.L. (1989). Posobie po intonatsii dlya inostrannykh studentov-filologov starshikh kursov [Teaching aid on intonation for foreign senior students of linguistics]: uchebnoe posobie. Moscow: Russkii yazyk.

Filin, F.P. (1979). Russkii yazyk. Entsiklopediya [The Russian language. Encyclopedia]. Moscow: Sovetskaya entsiklopediya.

Trebovaniya po russkomu yazyku kak inostrannomu. Povsednevnoe obshchenie. Postporogovyi uroven [Requirements for Russian as a foreign language. Everyday communication. Threshold level]. (2004). Moscow.

Khromov, S.S. (2000). Intonatsiya $\mathrm{v}$ sisteme yazyka i problemy metodicheskogo prognozirovaniya [Intonation in the system of language and the challenges of methodological prediction]: a monograph. Moscow: Izd-vo RUDN.

Khromov, S.S., Sokolova, L.A. (2014). Russkii yazyk kak inostrannyi v sisteme podgotovki inostrannykh magistrov [Russian as a foreign language in the training system of foreign Master students]. Vzaimodeistvie yazykov i kultur pri izuchenii russkogo yazyka inostrantsami. Tver: Tverskoi gos. un-t. 
Shutova, M.N. (2005). Lingvometodicheskie osnovy obucheniya fonetike russkogo yazyka inostrannykh studentov-filologov na zavershayushchem etape [Linguistic and methodological framework of teaching Russian phonetics to foreign students of linguistics at the final stage]: dissertation. ... Doctor of Pedagogic Sciences. Moscow: Pushkin State University.

Shutova, M.N. (2017). Intonatsionnyi analiz teksta na nachalnom etape obucheniya inostrannykh filologov-rusistov [Intonational text analysis at the initial stage of teaching foreign students of Russian studies]. Sb. materialov I Mezhdunarodnogo kongressa prepodavatelei i rukovoditelei podgotovitelnykh fakultetov. Moscow: Izd-vo RUDN.

Shutova, M.N. (2015). Rabochaya tetrad po fonetike i intonatsii russkogo yazyka dlya inostrannykh studentov urovnya B1-B2 [Workbook on phonetics and intonation of Russian for foreign students. Levels B1-B2]. Moscow.

Shcherba, L.V. (1957). Izbrannye raboty po russkomu yazyku [Selected works on the Russian language]. Moscow: Uchpedgiz.

Shutova, M.N., Khromov, S.S., Nesterova, T.V., Fathutdinova, V.G. (2019). Role of phonetics in forming the communicative competence of foreign russianist students. Opcion, 35(19), $1210-1225$.

Nesterova, T.V. (2012). Kontekstualno-situativnye rechevye akty-nameki v obikhodnom obshchenii russkikh. In the collection: Voprosy yazyka v sovremennykh issledovaniyakh. Moscow: Proceedings of the International scientific and practical conference "Slavyanskaya kultura: istoki, traditsii, vzaimodeistvie. XX Kirillo-Mefodievskie chteniya", 166-173.

Nesterova, T.V. (2015). Kosvennye realizatsii rechevykh intentsii v obikhodnom obshchenii russkikh [Indirect realizations of speech intention in everyday communication of Russians]. In the collection: Russkii yazyk i literatura $\mathrm{v}$ prostranstve mirovoi kultury. Proceedings of the XIII Congress of Kongressa MAPRYaL: in 15 volumes.

Nesterova, T.V. (2016) Kommunikativno-pragmaticheskii podkhod k opisaniyu yazykovykh edinits kak neobkhodimaya sostavlyayushchaya novoi russkoi grammatiki [Communicative and pragmatic approach to description of linguistic units as an integral part of new Russian grammar]. "Russkii yazyk za rubezhom", 3, 61-69.

Saveleva, E.P. (1991). Nominatsii rechevykh intentsii v russkom yazyke i ikh semantikopragmaticheskoe istolkovanie [Nomination of speech intentions in the Russian language and their semantic-pragmatic meaning]: Dissertation ... the Candidate of Philological Sciences. Moscow: In-t russkogo yazyka im. A. S. Pushkina. 